\title{
A new species of freshwater flatworm (Platyhelminthes, Tricladida, Dendrocoelidae) inhabiting a chemoautotrophic groundwater ecosystem in Romania
}

\author{
Giacinta Angela STOCCHINO ${ }^{1, *}$, Ronald SLUYS ${ }^{2}$, Mahasaru KAWAKATSU ${ }^{3}$, \\ Serban Mircea SARBU ${ }^{4} \&$ Renata MANCONI ${ }^{5}$ \\ 1,5 Dipartimento di Scienze della Natura e del Territorio, Università di Sassari, \\ Via Muroni 25, I-07100, Sassari, Italy. \\ ${ }^{2}$ Naturalis Biodiversity Center, P.O. Box 9517, 2300 RA Leiden, The Netherlands. \\ 39-jo 9-chome 1-8, Shinkotoni, Kita-ku, Sapporo, Hokkaido, Japan. \\ ${ }^{4}$ Department of Biological Sciences, California State University Chico, \\ Holt Hall Room 205, Chico CA 95929-515, USA. \\ "corresponding author: stocchin@uniss.it \\ ${ }^{2}$ Email: ronald.sluys@,naturalis.nl \\ ${ }^{3}$ Email: DQA01524@nifty.ne.jp \\ ${ }^{4}$ Email: serban.sarbu@yahoo.com \\ ${ }^{5}$ Email: $\underline{\text { rmanconi@uniss.it }}$

\footnotetext{
${ }^{1}$ urn:Isid:zoobank.org:author:A23390B1-5513-4F7B-90CC-8A3D8F6B428C

${ }^{2}$ urn:Isid:zoobank.org:author:8C0B31AE-5E12-4289-91D4-FF0081E39389

${ }^{3}$ urn:lsid:zoobank.org:author:56C77BF2-E91F-4C6F-8289-D8672948784E

${ }^{4}$ urn:lsid:zoobank.org:author:3A7EFBE9-5004-4BFE-A36A-8F54D6E65E74

${ }^{5}$ urn:Isid:zoobank.org:author:ED7D6AA5-D345-4B06-8376-48F858B7D9E3
}

\begin{abstract}
We report the description of a new species of freshwater flatworm of the genus Dendrocoelum inhabiting the chemoautotrophic ecosystem of Movile Cave as well as several sulfidic wells in the nearby town of Mangalia, thus representing the first planarian species fully described from this extreme biotope. The species was also found in non-sulfidic wells localized in villages in the vicinity of the cave with a total of nine examined populations. Dendrocoelum obstinatum Stocchino \& Sluys, sp. nov. represents the first triclad being able to live in both sulfidic and non-sulfidic waters. Among the fauna of the Mangalia sulfidic ecosystem it is the only species found also outside of the current boundaries of the sulfidic aquifer. One possible explanation of this peculiar distribution is that the new species is limited to the old boundaries of the sulfidic aquifer. The latter became much smaller during the hydrogeological history of the region, so that D. obstinatum may be considered to be an indicator of the extension of the sulfidic aquifer in the past of the Mangalia region. In the context of a biogeographic discussion on the distribution of the genus Dendrocoelum we provide an annotated checklist of species reported from Romania.
\end{abstract}

Keywords. Stygofauna, Movile Cave, sulfidic habitat, Dendrocoelum, Western Palaearctic Region. 
Stocchino G.A., Sluys R., Kawakatsu M., Sarbu S.M. \& Manconi R. 2017. A new species of freshwater flatworm (Platyhelminthes, Tricladida, Dendrocoelidae) inhabiting a chemoautotrophic groundwater ecosystem in Romania. European Journal of Taxonomy 342: 1-21. https://doi.org/10.5852/ejt.2017.342

\section{Introduction}

The freshwater planarian fauna of Romania, in particular from groundwater habitats, has been the subject of several studies that were developed since the 1920s, notably by De Beauchamp and Codreanu (De Beauchamp 1928, 1929, 1932, 1949; Codreanu 1929, 1943, 1949; see also Del Papa 1965; Codreanu \& Balcesco 1967a, 1967b, 1967c, 1970; Gourbault 1967a, 1967b). This interest in subterranean animals in Romania is not surprising, considering that biospeleology as a formal science was created in 1907 by the Romanian scientist Emile Racoviţă, who also promoted at Cluj in 1920 the foundation of the first Institute of Speleology of the world (cf. Negrea 2007 and references therein).

Subterranean triclads from Romania belong to two genera of the family Dendrocoelidae (Dendrocoelum Örsted, 1844, Polycladodes Steinmann, 1910) and two genera of Planariidae (Atrioplanaria De Beauchamp, 1932, Crenobia Kenk, 1930) (cf. Gourbault 1972, 1986). With respect to epigean species, the following taxa were recorded: Dugesia sp., Schmidtea lugubris (Schmidt, 1861), S. polychroa (Schmidt, 1861), Polycelis felina (Dalyell, 1814), P. nigra (Müller, 1774), and P. tenuis Ijima, 1884 (cf. Dahm \& Gourbault 1978).

The genus Dendrocoelum contains about 90 nominal species with a Palaearctic distribution, the majority of which (ca 56) are inhabitants of groundwaters (cf. Gourbault 1972, 1986; Dahm \& Gourbault 1978; Kenk 1978; Bromley 1982; Dyganova 1988; Sluys \& Benazzi 1992; Vila-Farrè et al. 2011; Harrath et al. 2012; Sluys 2012; Stocchino et al. 2013).

In this paper we present the description of a new species of Dendrocoelum inhabiting the chemoautotrophic ecosystem of Movile Cave as well as several sulfidic hand-dug wells nearby the cave, representing the first fully described triclad from this extreme biotope. Movile Cave (southeastern Dobrogea, Romania) represents the first chemoautotrophic groundwater ecosystem ever described, and is one of the key models studied to date. The cave has been cut off from the outside world for about 5 million years and although it lacks any input of photoautotrophically based food, it is inhabited by a rich invertebrate community of 48 species, including 34 endemics, thus representing the only cave ecosystem in the world with such a high value of endemicity (Sarbu \& Popa 1992; Sarbu et al. 1996; Sarbu 2000). The presence of this new species of Dendrocoelum also in non-sulfidic wells is here also reported and discussed.

In the context of a biogeographic discussion on the distribution of species of Dendrocoelum we provide an annotated checklist of species reported from Romania.

\section{Material and methods}

For the morphological study, specimens were fixed for 24 hours in Bouin's fluid, dehydrated in a graded ethanol series, cleared in clove oil and then embedded in synthetic wax or paraffin. Serial sections were made at intervals of $8 \mu \mathrm{m}$ and stained with Mallory-Heidenhain or Delafield's hematoxylin and erythrosin. All specimens were fixed just after collection. Specimens from Movile Cave were fixed either inside the cave or in a laboratory very close to the cave. This practice was necessary because attempts to keep the worms alive failed and animals died rapidly, very likely due to changes in water temperature and/or water chemistry.

The material is deposited in Naturalis Biodiversity Center, Leiden, The Netherlands (ZMA collection code) and in the Giacinta A. Stocchino Collection (CGAS), University of Sassari. 


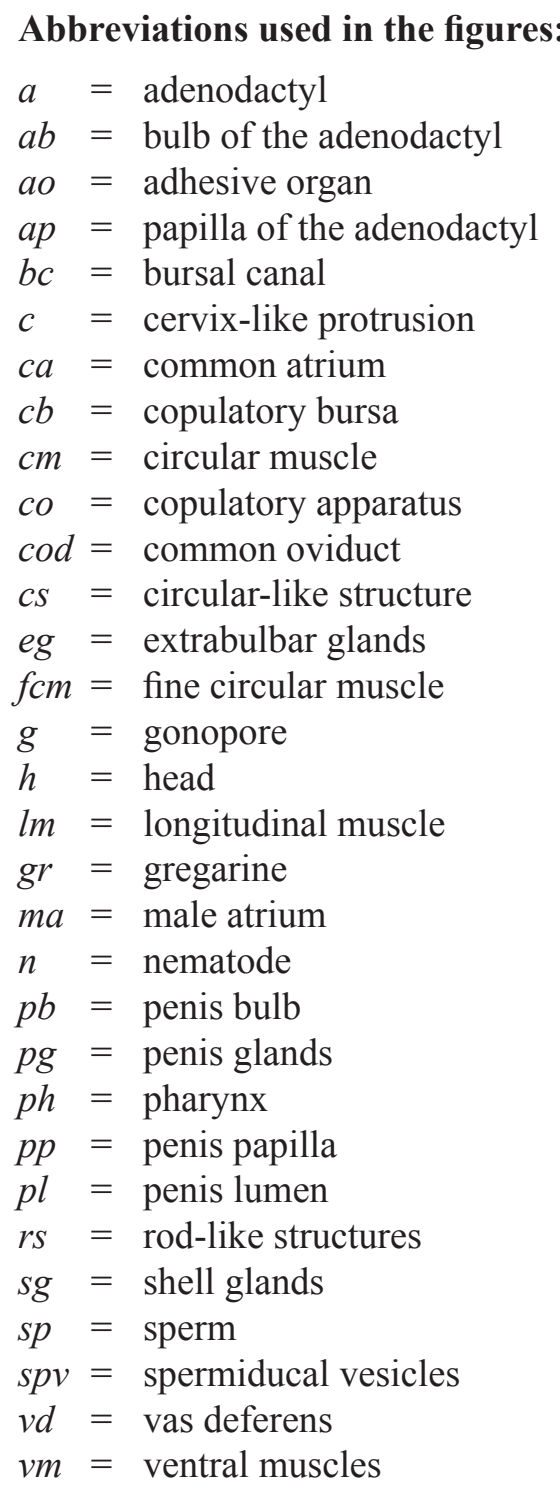

\section{Results}

Order Tricladida Lang, 1884

Suborder Continenticola Carranza, Littlewood, Clough, Ruiz-Trillo, Baguña \& Riutort, 1998

Superfamily Planarioidea Stimpson, 1857

Family Dendrocoelidae Hallez, 1892

Genus Dendrocoelum Örsted, 1844

Dendrocoelum obstinatum Stocchino \& Sluys, sp. nov. urn:1sid:zoobank.org:act:28FF68D5-C4C2-42F0-8DD3-223D2E32CCA0

Figs $1-5$, Tables $1-2$

\section{Diagnosis}

Dendrocoelum obstinatum Stocchino \& Sluys, sp. nov. is characterized by: a male atrium extending ventrally to form a cervix-like structure projecting into the common atrium; a proximal tract of the bursal canal with an almost non-existent lumen; testes extending to the far posterior end of the body; a Balkan type of adenodactyl, with a length approximately equal to that of the penis; the penis being 
in a dorsal position and the adenodactyl located ventrally; the proximal half of the bursal canal being surrounded by a subepithelial layer of longitudinal muscle, while its distal half is surrounded by a subepithelial layer of circular muscles, followed by a layer of longitudinal fibres.

\section{Etymology}

The specific epithet is derived from the Latin adjective 'obstinatus', firm, stubborn, obstinate, and alludes to the fact that the species lives in subterranean waters without hydrogen sulphide but is also able to live in and withstand sulfidic groundwaters.

\section{Material examined}

\section{Holotype}

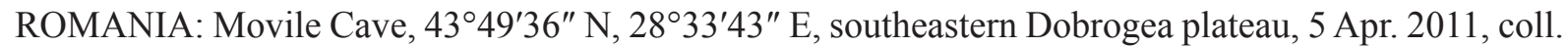
S.M. Sarbu, sagittal sections (sag. sect.), 4 slides (ZMA V.P1. 7264.1).

\section{Paratypes}

ROMANIA: same data as for holotype, sag. sect., 4 slides (ZMA V.P1. 7264.2); same data as for holotype, sag. sect., 4 slides (ZMA V.P1. 7264.3); same data as for holotype, 1 entire immature specimen preserved in ethanol (ZMA V.P1. 7264).

\section{Other material}

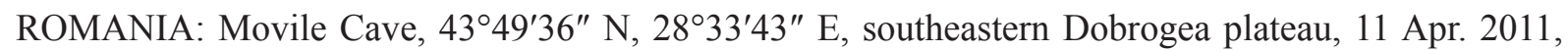
coll. S.M. Sarbu, sag. sect., 6 slides (ZMA V.P1. 7265.1); same data as previous, sag. sect., 3 slides (ZMA V.Pl. 7265.2); same data as previous, 5 entire immature specimens preserved in ethanol (ZMA V.P1.

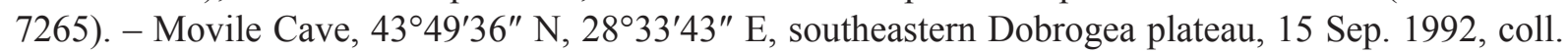
S.M. Sarbu, sag. sect., 3 slides (ZMA V.Pl. 1750.1); same data as previous, sag. sect., 2 slides, immature

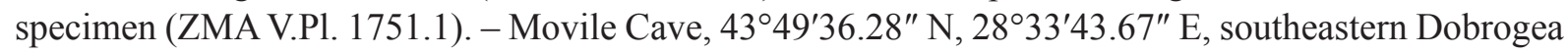
plateau, 19 Dec. 1992, coll. S.M. Sarbu, sag. sect., 2 slides, immature specimen (ZMA V.Pl. 1752.1). -

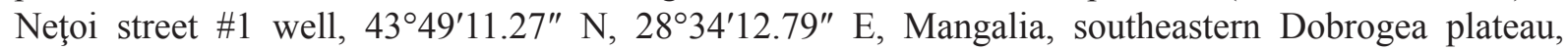
28 Aug. 1992, coll. S.M. Sarbu, sag. sect., 4 slides (ZMA V.P1. 1746.1); same data as previous, sag. sect., 3 slides (ZMA V.Pl. 1746.2); same data as previous, sag. sect., 2 slides (ZMA V.Pl. 1746.3); same data as previous, sag. sect., 4 slides (ZMA V.Pl. 1746.4); same data as previous, sag. sect., 3 slides (ZMA V.P1. 1746.5). - Neţoi street \#1 well, 4349'11.27" N, 28³4'12.79" E, Mangalia, 21 Jun. 1993, coll. S.M. Sarbu, sag. sect., 5 slides (ZMA V.Pl. 1753.1); same data as previous, sag. sect., 5 slides (ZMA V.Pl. 1754.1); same data as previous, sag. sect., 3 slides (ZMA V.Pl. 1754.2); same data as previous, sag.

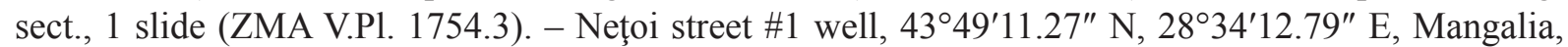
southeastern Dobrogea plateau, 5 Apr. 2001, coll. S.M. Sarbu, sag. sect., 3 slides (ZMA V.Pl. 7266.1); same data as previous, sag. sect., 4 slides (ZMA V.Pl. 7266.2); same data as previous, sag. sect., 4 slides (ZMA V. Pl. 7266.3); same data as previous, one entire immature specimen preserved in ethanol (ZMA V.Pl. 7266); same data as previous, sag. sect., 5 slides (CGAS Pla 11. 1); same data as previous, sag. sect., 5 slides (CGAS Pla 11. 2); same data as previous, sag. sect., 4 slides (CGAS Pla 11. 3); same data as previous, 6 entire immature specimens preserved in ethanol (CGAS Pla 11). - Horia, Cloşca \& Crişan

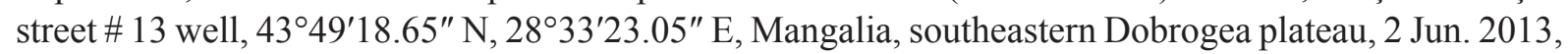
coll. S.M. Sarbu, sag. sect., 13 slides (CGAS Pla 12. 1); same data as previous, sag. sect., 14 slides (CGAS Pla 12.2), same data as previous, 11 entire immature specimens preserved in ethanol (CGAS Pla 12). - Aleea Cetăţii street \# 1well, 4348'52.95" N, 28 35'03.37" E, Mangalia, southeastern Dobrogea plateau, 28 Aug. 1992, coll. S.M. Sarbu, sag. sect., 10 slides (ZMA V.P1. 1747.1); same data as previous, sag. sect., 6 slides (ZMA V.Pl. 1747.2); same data as previous, sag. sect., 8 slides (ZMA V.Pl. 1747.3); same data as previous, sag. sect., 7 slides (ZMA V.Pl. 1747.4); same data as previous, sag. sect., 11 slides (ZMA V.Pl. 1747.5); same data as previous, horizontal sections (hor. sect.), 4 slides (ZMA V.P1. 1747.6). 


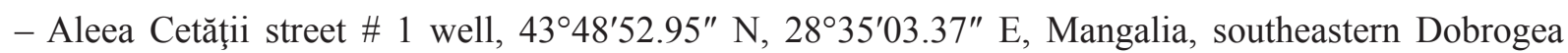
plateau, 2 Jun. 2013, coll. S.M. Sarbu, sag. sect., 8 slides (CGAS Pla 13. 1); same data as previous, sag. sect., 6 slides (CGAS Pla 13. 2); same data as previous, sag. sect., 7 slides (CGAS Pla 13. 3); same data as previous, sag. sect., 8 slides (CGAS Pla 13. 4); same data as previous, hor. sect., 6 slides (CGAS Pla 13. 5); same data as previous, sag. sect., 6 slides (CGAS Pla 13. 6); same data as previous, 21 entire immature specimens preserved in ethanol (CGAS Pla 13). - General Dragalina street \# 10 well,

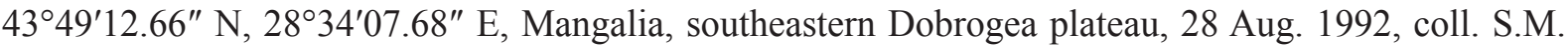
Sarbu, sag. sect., 5 slides (ZMA V.Pl. 1748.1); same data as previous, sag. sect., 3 slides (ZMA V.Pl. 1748.2); same data as previous, sag. sect., 4 slides (ZMA V.Pl. 1748.3); same data as previous, sag. sect., 3 slides (ZMA V.Pl. 1748.4); same data as previous, sag. sect., 4 slides (ZMA V.Pl. 1748.5); same data as previous, sag. sect., 2 slides (ZMA V.Pl. 1748.6); same data as previous, sag. sect., 5 slides (ZMA V.Pl. 1748.7); same data as previous, sag. sect., 3 slides (ZMA V.P1. 1748.8); same data as previous, sag. sect., 4 slides (ZMA V.Pl. 1748.9); same data as previous, hor. sect., 4 slides (ZMA V.Pl. 1748.10); same data as previous, transverse sections (transv. sect.), 7 slides (ZMA V.Pl. 1748.11). - 2 (Doi) Mai well, 434'19.77" N, 28³4'34.82" E, southeastern Dobrogea plateau, 19 Nov. 1993, coll. S.M. Sarbu and D. Dancau, sag. sect., 22 slides (ZMA V.Pl. 1755.1); same data as previous, sag. sect., 6 slides (ZMA V.Pl. 1755.2); same data as previous, sag. sect., 5 slides ZMA V.Pl. 1755.3 - 2 (Doi) Mai well, 4347'19.77" N, $28^{\circ} 34^{\prime} 34.82^{\prime \prime}$ E, southeastern Dobrogea plateau, Romania, 11 Apr. 2011, coll. S.M. Sarbu, sag. sect., 4 slides (ZMA V.Pl. 7267.1); same data as previous, sag. sect., 5 slides (ZMA V.P1. 7267.2); same data as previous, sag. sect., 4 slides (ZMA V.Pl. 7267.3); same data as previous, sag. sect., 5 slides (CGAS Pla 14. 1); same data as previous, sag. sect., 6 slides (CGAS Pla 14. 2); same data as previous, sag. sect., 3 slides (CGAS Pla 14. 3); same data as previous, sag. sect., 3 slides (CGAS Pla 14. 4); same data as previous, sag. sect., 6 slides (CGAS Pla 14. 5); same data as previous, sag. sect., 3 slides (CGAS Pla 14. 6); same data as previous, hor. sect., 2 slides (CGAS Pla 14. 7); same data as previous, 3 entire immature specimenspreservedinethanol(CGASPla 14).-Limanuwell, $43^{\circ} 48^{\prime} 00.22^{\prime \prime} \mathrm{N}, 28^{\circ} 31^{\prime} 34.82^{\prime \prime}$ E, southeastern Dobrogea plateau, 28 Aug. 1992, coll. S.M. Sarbu, sag. sect., 5 slides (ZMA V.Pl. 1749.1); same data as previous, sag. sect., 3 slides (ZMA V.P1. 1749.2); same data as previous, sag. sect., 4 slides (ZMA V.P1. 1749.3); same data as previous, sag. sect., 4 slides (ZMA V.Pl. 1749.4); same data as previous, sag. sect., 6 slides (ZMA V.Pl. 1749.5); same data as previous, sag. sect., 4 slides (ZMA V.Pl. 1749.6); same data as previous, sag. sect., 6 slides (ZMA V.Pl. 1749.7); same data as previous, sag. sect., 3 slides (ZMA V.Pl. 1749.8); same data as previous, sag. sect., 4 slides (ZMA V.Pl. 1749.9); same data as previous, sag. sect., 4 slides (ZMA V.Pl. 1749.10); same data as previous, hor. sect., 4 slides (ZMA V.Pl. 1749.11);

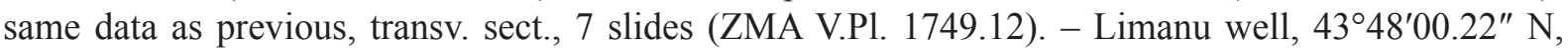
$28^{\circ} 31^{\prime} 34.82^{\prime \prime}$ E, southeastern Dobrogea plateau, 3 Apr. 2011, coll. S.M. Sarbu, sag. sect., 3 slides (ZMA V.Pl. 7268.1); same data as previous, sag. sect., 3 slides (ZMA V.P1. 7268.2); same data as previous, 3 entire immature specimens preserved in ethanol (ZMA V.Pl. 7268); same data as previous, sag. sect., 3 slides (CGAS Pla 15. 1); same data as previous, sag. sect., 2 slides (CGAS Pla 15. 2); same data as previous, sag. sect., 2 slides (CGAS Pla 15. 3); same data as previous, transv. sect., 6 slides (CGAS Pla 15. 4); same data as previous, transv. sect., 3 slides (CGAS Pla 15. 5); same data as previous, 12 entire immature specimens preserved in ethanol (CGAS Pla 15). - Limanu well, 43 $48^{\prime} 00.22^{\prime \prime} \mathrm{N}$, 28 31'34.82" E, southeastern Dobrogea plateau, 11 Apr. 2011, coll. S.M. Sarbu, sag. sect., 2 slides (ZMA V.Pl. 7269.1); same data as previous, sag. sect., 4 slides (ZMA V.Pl. 7269.2); same data as previous, one entire immature specimen preserved in ethanol (ZMA V.Pl. 7269); same data as previous, hor. sect., 2 slides (CGAS Pla 16. 1); same data as previous, hor. sect., 2 slides (CGAS Pla 16. 2); same data as previous, 7 entire immature specimens preserved in ethanol (CGAS Pla 16). - Albeşti well, $43^{\circ} 48^{\prime} 45.63^{\prime \prime}$ N, 28 25'37.05" E, southeastern Dobrogea plateau, 6 Apr. 2011, coll. S.M. Sarbu, sag. sect., 7 slides (ZMA V.Pl. 7270.1); same data as previous, sag. sect., 8 slides (ZMA V.Pl. 7270.2); same data as previous, sag. sect., 8 slides (ZMA V.Pl. 7270.3); same data as previous, 20 entire immature specimens preserved in ethanol (ZMA V.Pl. 7270). - Vama Veche well, 43 ${ }^{\circ} 45^{\prime} 07.10^{\prime \prime} \mathrm{N}$, $28^{\circ} 34^{\prime} 20.48^{\prime \prime}$ E, southeastern Dobrogea plateau, 17 May 1993, coll. S.M. Sarbu and D. Dancau, sag. 


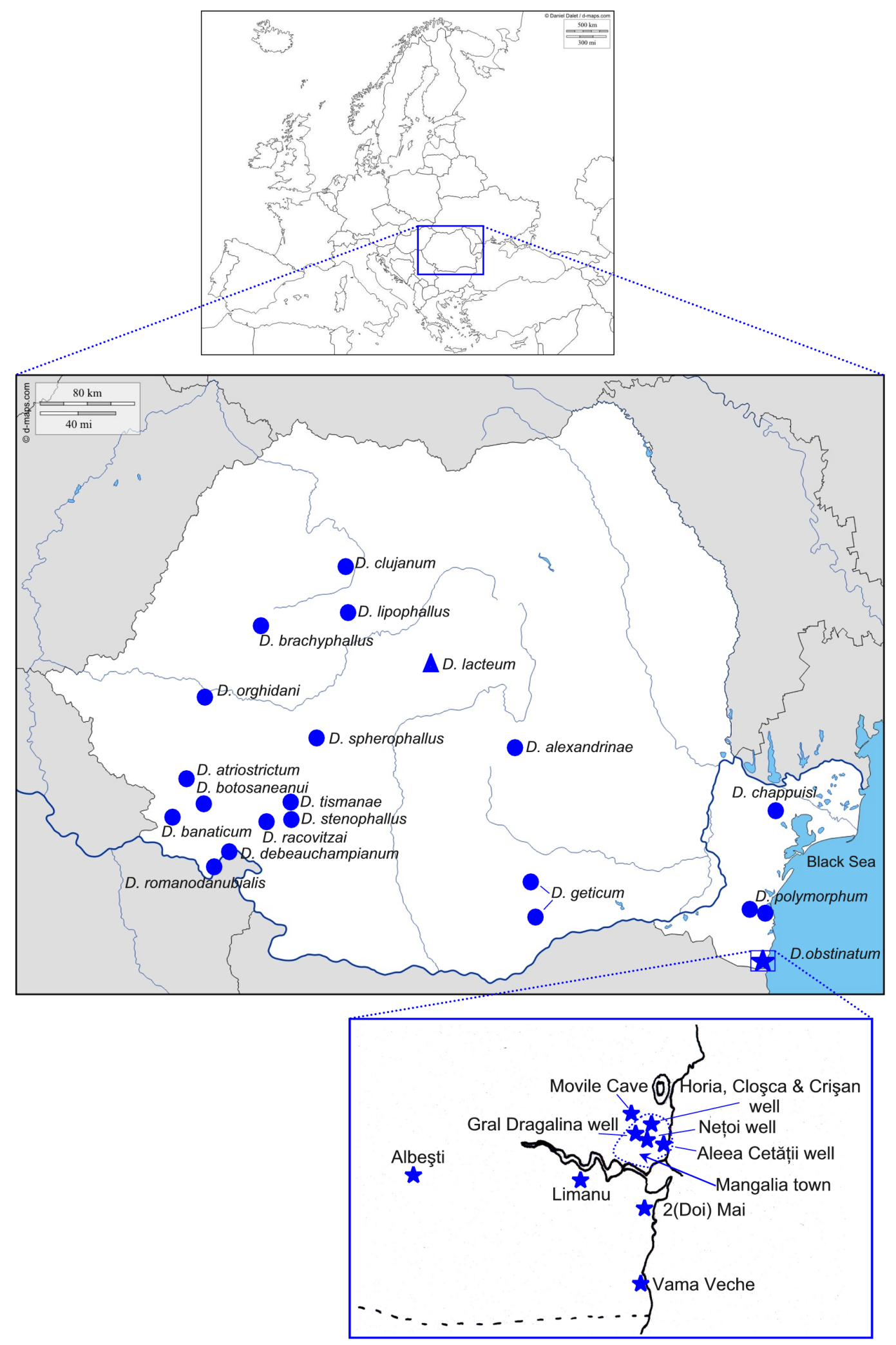

Fig. 1. Geographic distribution of freshwater planarians of the genus Dendrocoelum recorded from Romania. $\mathbf{\Delta}$ : unspecified locality of D. lacteum Müller, 1774. Rectangular inset (bottom) corresponds with enlarged area, showing the collection sites of $D$. obstinatum Stocchino \& Sluys, sp. nov. indicated by blue stars (see also Table 1). 
sect., 8 slides (ZMA V.Pl. 1756.1); same data as previous, sag. sect., 8 slides (ZMA V.Pl. 1756.2); same data as previous, sag. sect., 7 slides (ZMA V.Pl. 1756.3); same data as previous, sag. sect., 5 slides (ZMA V.Pl. 1756.4); same data as previous, sag. sect., 6 slides (ZMA V.Pl. 1756.5); same data as previous, sag. sect., 7 slides (ZMA V.Pl. 1756.6); same data as previous, sag. sect., 5 slides (ZMA V.Pl. 1756.7); same data as previous, sag. sect., 6 slides (ZMA V.Pl. 1756.8); same data as previous, sag. sect., 4 slides (ZMA V.Pl. 1756.9); same data as previous, sag. sect., 6 slides (ZMA V.Pl. 1756.10); same data as previous, sag. sect., 7 slides (ZMA V.Pl. 1756.11); same data as previous, hor. sect., 4 slides (ZMA V.Pl. 1756.12); same data as previous, transv. sect., 8 slides (ZMA V.Pl. 1756.13).

\section{Description}

Live animals unpigmented, typically whitish, and lacking eyes. Preserved mature specimens measured $3-8 \mathrm{~mm}$ in length, and $1-2 \mathrm{~mm}$ in width. The anterior end is truncated, with the middle part of the frontal margin convex, and is provided with a pair of rounded lateral lobes (Fig. 2).

The subterminal anterior adhesive organ is moderately developed and consists of a shallow cup made up of infranucleated epithelial cells, which are pierced by numerous openings of erythrophil glands. The musculature associated with this organ consists of a more strongly developed section of the usual ventral longitudinal body musculature (Fig. 4B).

In specimens from Movile Cave (holotype ZMA V.P1. 7264.1, ZMA V.P1. 7264.2, ZMA V.P1. 7264.3, ZMA V.Pl. 7265.1, ZMA V.P1. 7265.2 and ZMA V.Pl. 1751.1), and in all specimens from Neţoi well, the main gut branches, their diverticula, as well as pharyngeal pouch house numerous specimens of a gregarine protozoan probably belonging to the genus Monocystella Valkanov, 1934 (I. Desportes, Muséum national d'Histoire naturelle, Paris, pers. comm.) (Fig. 5A).

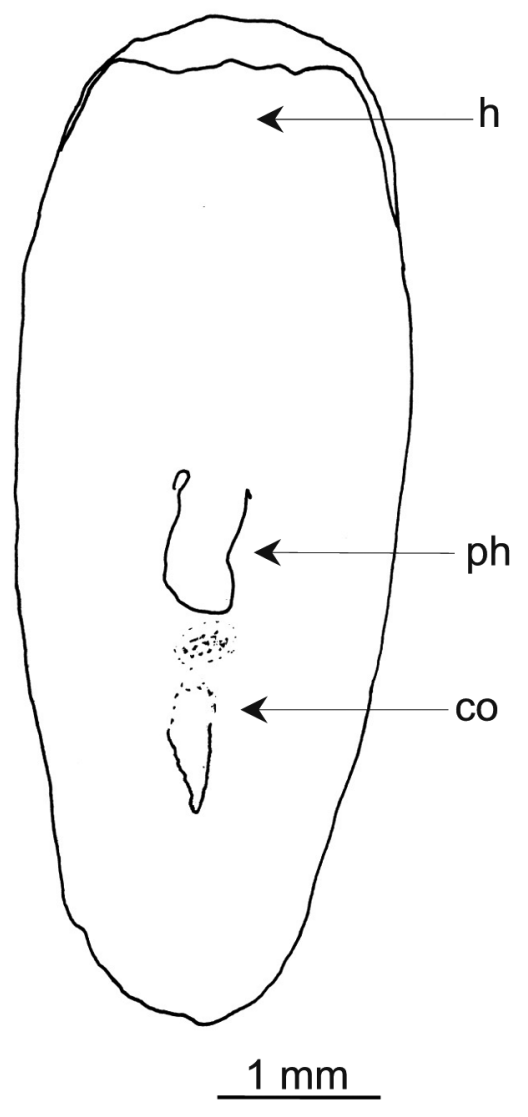

Fig. 2. Dendrocoelum obstinatum Stocchino \& Sluys, sp. nov. Sketch of the ventral view of a preserved (Bouin's fluid) specimen from Movile Cave. 
The pharynx is located in the posterior half of the body and measures about $1 / 6^{\text {th }}$ of the body length (Fig. 2). Its internal muscle zone consists of a very thick layer of intermingled circular and longitudinal fibres. A subepithelial layer of longitudinal muscles, followed by a layer of circular fibres forms the thin outer zone of muscles.
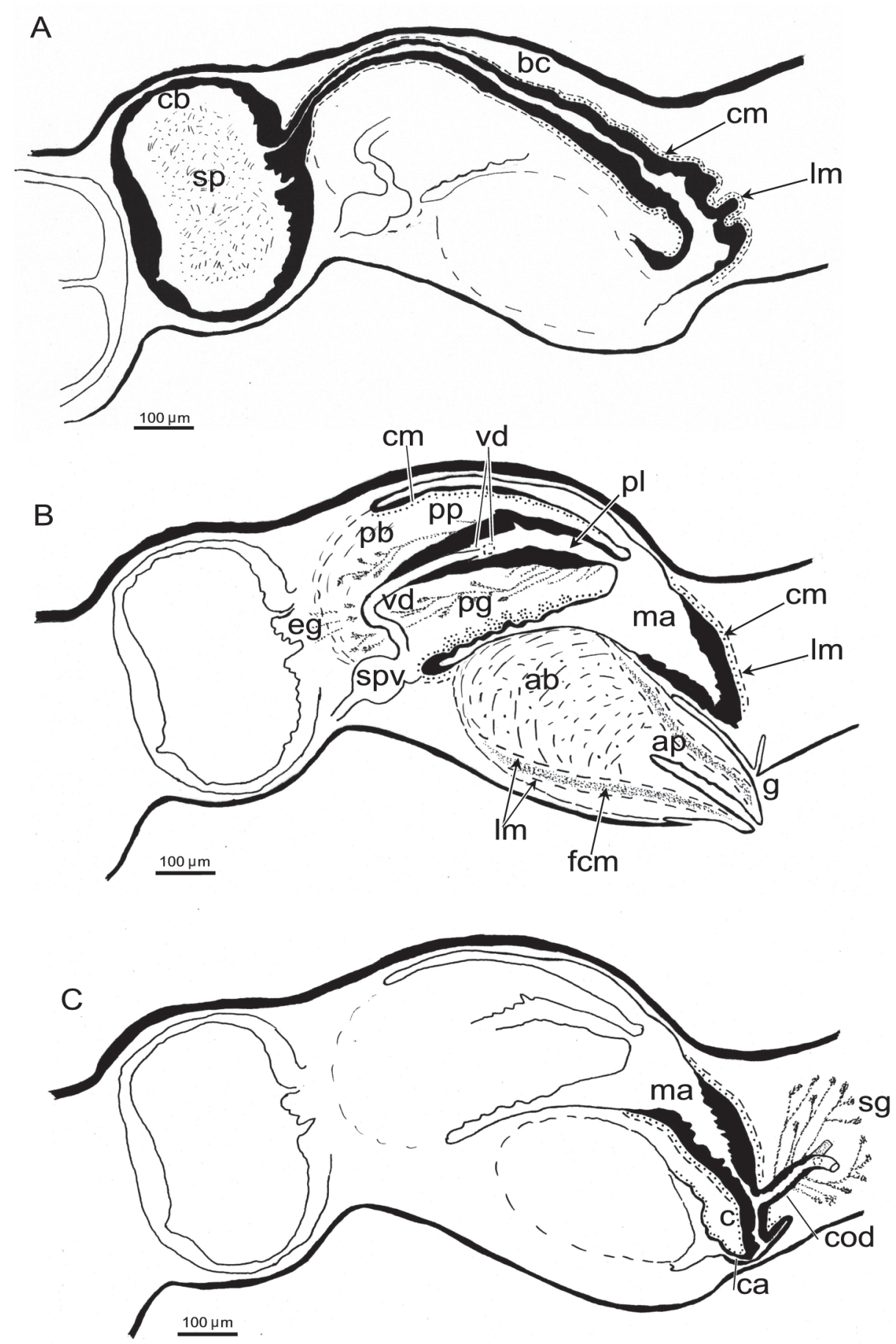

Fig. 3. Dendrocoelum obstinatum Stocchino \& Sluys, sp. nov., holotype (ZMA V.P1. 7264.1). A. Sagittal reconstruction of the female copulatory apparatus (anterior to the left). B. Sagittal reconstruction of the male copulatory apparatus (anterior to the left). Only the terminal portions of the spermiducal vesicles are drawn. C. Sagittal reconstruction of the male copulatory apparatus with the cervix-like protrusion (anterior to the left). 
The ventral ovaries are located at $14^{\text {th }}$ of the distance between the brain and the root of the pharynx, and at $1 / 10^{\text {th }}$ of the distance between the brain and the posterior end of the body. The oviducts originate from the postero-lateral part of the ovaries and are provided with a very slight expansion at their anterior end, thus forming the tuba. The oviducts run posteriorly, recurve posterior to the gonopore and, subsequently, fuse to form a common oviduct. The common oviduct runs anteriorly to the right side of the bursal canal to open into the distal, ventro-posterior part of the male atrium, representing the cervix-like protrusion of the latter (see below). The common oviduct receives numerous openings of erythrophil shell glands along $3 / 4$ of its entire length (Figs $3 \mathrm{C}, 4 \mathrm{~A}, \mathrm{C}$ ).

Well developed, rounded resorptive vesicles are present at least along the oviducts of ZMA V.P1. 7265.1 from Movile Cave, ZMA V.Pl. 1749.8 from the Limanu well, ZMA V.Pl. 1756.4, ZMA V.P1. 1756.7 from the Vama Veche well and ZMA V.Pl. 1747.1 from the Aleea Cetăţii well. Each vesicle communicates with the oviduct through a short, narrow ductule. Sperm is present, both in the oviducal lumen and in the short interconnecting ductules.

The well developed testes are numerous and basically dorsal in position. In ZMA V.P1.7270.1, ZMA V.Pl. 7270.3 (Albeşti well), CGAS Pla 12. 1 (Horia Cloşca and Crişan well), and ZMA V.Pl. 1756.9 (Vama Veche well) testes are present also in ventral position, while some follicles are situated in the middle of the body. The testes extend from a short distance behind the ovaries to far into the posterior end of the body.

The sperm ducts form well-developed spermiducal vesicles, packed with sperm, between the mouth and the anterior level of the penis bulb (Fig. 3B). Thereafter the ducts curve to the dorsal side, in some cases (ZMA V.Pl. 1749.8, ZMA V.P1. 1749.9, ZMA V.P1. 1749.10 and ZMA V.Pl. 1749.12 from the Limanu well, as well as ZMA V.P1. 1755.1 from 2 (Doi) Mai well) reaching the dorsal part of the body, and, subsequently, separately penetrate the penis bulb from the antero-lateral sides to open symmetrically and closely together into the anterior section of the lumen of the penis papilla (Fig. 3B). In specimens ZMA V.P1. 7268.2, and ZMA V.Pl. 1749.7 from Limanu well the right vas deferens enters the penis bulb ventrally to the left one.

The copulatory apparatus occupies the anterior half of the postpharyngeal region. The copulatory bursa, situated just behind the pharynx, is sac-shaped and occupies the entire dorso-ventral space of the body. The bursa is lined with a cuboidal to columnar glandular epithelium and is surrounded by a layer of longitudinal muscles (Figs 3, 4A). The bursa contains a mass of sperm that is not enveloped by a spermatophore. This mass is not homogeneous, but within it scattered rod-like structures are recognizable. These structures have a sclerotic-like appearance, are of various lengths and more intensely stained as compared to the rest of the mass of sperm (Fig. 5C). Besides the holotype, such rod-like structures are present in ZMA V.P1. 7265.1 and ZMA V.Pl. 7265.2 from Movile Cave and also in the copulatory bursa of CGAS Pla 13. 1 from the Aleea Cetăţii well and in ZMA V.P1. 7270.1 from the Albeşti well. In ZMA V.P1. 7269.1 from the Limanu well the sperm mass inside the copulatory bursa is characterized by circular structures with a multilayered concentric organization (Fig. 5D).

The bursal canal runs posteriorly to the left of the penis. In almost all specimens examined the lumen of first tract of the canal is so much reduced that it can be considered to be almost non-existent, after which it gradually widens slightly, the canal subsequently turning ventrally, becoming more wide and opening into the common atrium (Fig. 3A). The wall of the bursal canal consists of a nucleated epithelium, which gradually changes from being cuboidal in the proximal tract to become cylindrical in the more distal section of the canal. The epithelial cells are provided with very long cilia that fill the bursal canal lumen from its proximal tract to ca $3 / 4$ of its length; in the distal tract of the canal, however, the cilia are much more sparse. The proximal half of the canal is surrounded by a subepithelial layer of longitudinal 
muscle, while its distal half is surrounded by a subepithelial layer of circular muscles, followed by a layer of longitudinal fibres (Fig. 3A).

The penis is located dorsally to the adenodactyl (Figs 3B, 4A), while the bursal canal is situated to the left of the midline of the body. The penis is approximately of the same length as the adenodactyl. In some specimens, such as in ZMA V.Pl. 7270.3 from the Albeşti well, the penis papilla is longer than the adenodactyl.

The muscular penis bulb is rather small; the papilla is about three times as large as the penis bulb. The penis papilla is covered with a thin epithelium at its apical part that becomes thicker at the basal part of the papilla. This epithelium is underlain by a thick layer of circular muscle, which is absent at the very tip of the penis papilla. The penis papilla is slightly asymmetrical, with the ventral part being somewhat larger than the dorsal one because of the dorsally displaced position of the lumen of the penis papilla (Figs 3B, 4A).

In the majority of the specimens examined the penis papilla is conical, however, its shape is variable and thus it may be more or less elongated or shortened, depending on the state of contraction. This implies also a certain variability in the length, width, and position of the papilla lumen, in that in some animals
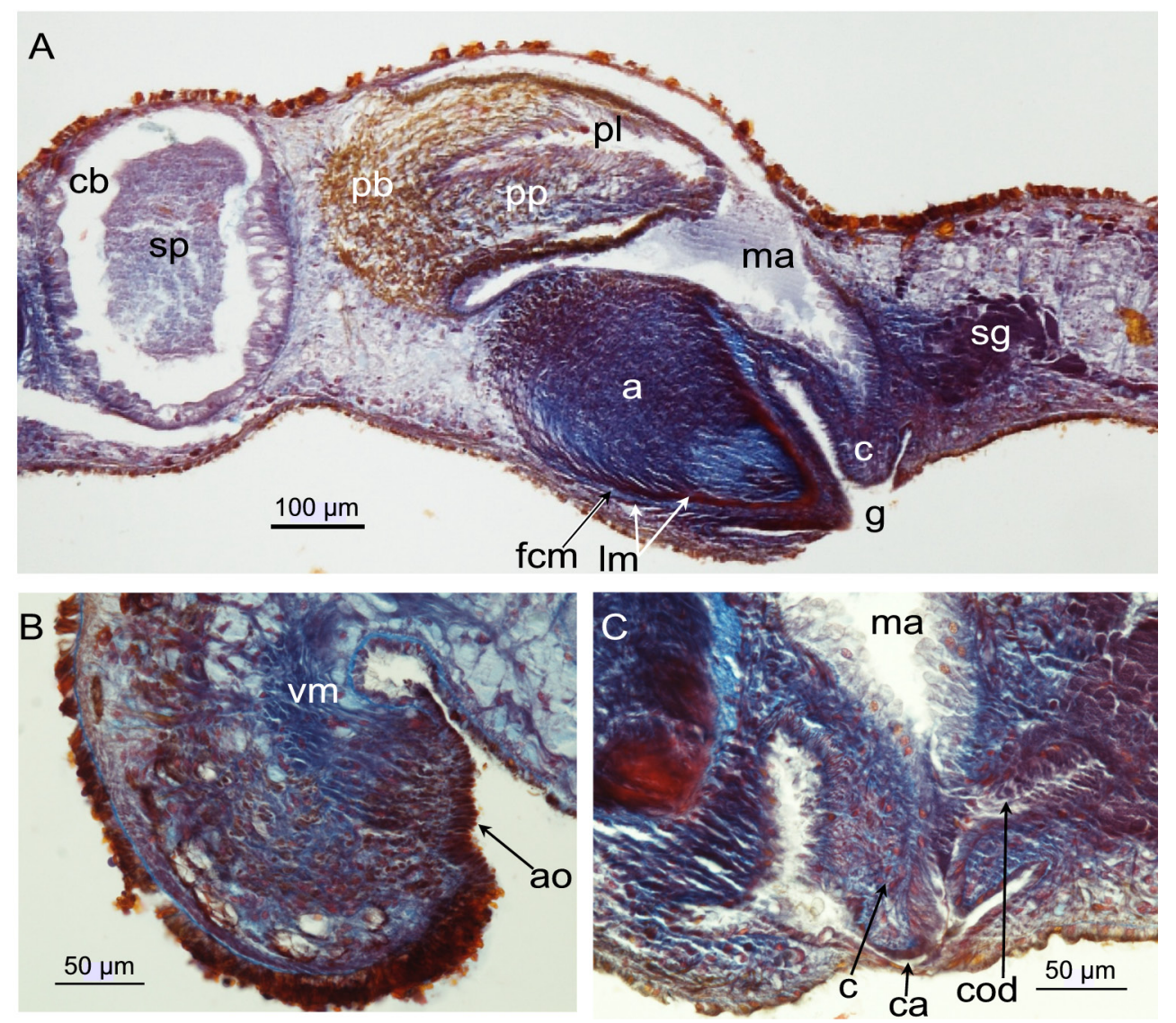

Fig. 4. Dendrocoelum obstinatum Stocchino \& Sluys, sp. nov., holotype (ZMA V.P1. 7264.1). A. Microphotograph of the copulatory apparatus. B. Microphotograph of the anterior adhesive organ with the associated ventral muscles. C. Microphotograph of the cervix-like protrusion of the male atrium, with the opening of the common oviduct. 
it is displaced towards the center of the penis papilla, in contrast to the more dorsal position in most of the specimens examined.

The penis is rich in glands, which in the holotype are located mainly in the penis bulb and in the ventral part of the penis papilla. Some extrabulbar glands are also present. All of these glands open into the penis lumen, which is full of secretion, as is the male atrium. In all specimens examined it was impossible to detect traces of spermatophores, neither in the penial lumen, nor the male atrium, nor inside the copulatory bursa (Figs 3, 4A).

The adenodactyl is very large and consists of a free papilla and a well-developed bulbar part. In the holotype and in many other specimens examined the apical part of the adenodactyl is thrust out of the body (Figs 3B, 4A), a condition very likely due to preservation artefacts. The bulb consists of intermingled rows of longitudinal and circular muscle, bounded by a thin layer of longitudinal fibres. The very small lumen of the adenodactyl is lined by a layer of ciliated cells and it is surrounded by a well developed zone of mesenchymatic tissue. Through this section of the mesenchyme runs a thick layer of fine circular muscle fibres. Ectally and internally to this zone of circular muscles runs a thin layer of longitudinal muscle fibres (Figs 3B, 4A). In the specimens stained in Mallory-Heidenhain, this layer of fine circular fibres is pale blue, while the longitudinal fibres stain red and the intermingled muscles stain bright blue. Many erythrophilic glands open into the adenodactyl lumen.

In ZMA V.P1. 7265.2 from Movile Cave a nematode specimen infected the bulb of the adenodactyl and stained red with Mallory-Heidenhain (Fig. 5B).

The male atrium is lined by a columnar, nucleated epithelium and is surrounded by a subepithelial layer of circular muscles, followed by a layer of longitudinal fibers. The male atrium communicates with the common atrium through a cervix-like protrusion, which extends ventrally to some extent, with the result that the lumen of the common atrium is virtually non-existent. In this cervix-like protrusion the male atrium receives the opening of the common oviduct, which is lined by a nucleated epithelium (Figs 3C, $4 \mathrm{~A}, \mathrm{C})$.

\section{Geographical distribution}

Exclusively known from the Movile Cave, wells in the town of Mangalia, and wells in the villages of Limanu, 2 (Doi) Mai, Albeşti and Vama Veche in Romania.

\section{Habitat}

\section{Movile Cave}

This is a land-locked cave and represents the first chemoautotrophically based groundwater ecosystem ever described. This cave system is developed in oolitic and fossil-rich limestone of Sarmatian age (ca 12.5 Ma). It consists of a network of upper dry cave passages, ca $200 \mathrm{~m}$ long, and a lower level cave ca $40 \mathrm{~m}$ long, partially flooded by thermomineral waters rich in hydrogen sulphide, forming a lake and some air pockets. Geophysical investigations, water chemistry, and stable isotope data indicate that this maze of fissures is part of an extensive sulfidic groundwater aquifer that spreads out over an area of ca $70 \mathrm{~km}^{2}$ (cf. Sarbu 2000 and references therein). The thermal sulfidic groundwaters at Mangalia ascend along natural geological faults from a confined aquifer at a depth of 200-400 m (this pressurized water with a temperature of $25^{\circ} \mathrm{C}$ contains $\mathrm{H}_{2} \mathrm{~S}, \mathrm{CH}_{4}, \mathrm{NH}_{4}^{+}$and lacks $\mathrm{O}_{2}$ ) under the Sarmatian limestones and flood the superficial carbonate bedrock up to the groundwater level. The submerged portion of the cave contains microbial mats composed of chemoautotrophic sulfide-oxidizing bacteria as well as fungi, which float on the water surface and grow on the limestone walls. The subterranean ecosystem is based entirely on food produced in situ by these chemoautotrophic organisms (cf. Sarbu 2000 and references therein). 
Flatworm specimens were collected along the shore of the lake where water temperature is constantly $21^{\circ} \mathrm{C}$ all year round, with absolutely no fluctuations; $\mathrm{pH}$ value is 7.29 (Table 1 ). The worms were found gliding on sediment in very shallow water and never went any deeper than one centimetre, due to the fact that oxygen is present only at the surface and in the first one millimetre of water, while all of the deep water is completely anoxic (Riess et al. 1999). Planarians were seen moving upside-down, thus having access to oxygenated water. Only a few flatworm specimens were found per collection.

Planarians were found associated with a diverse invertebrate fauna, consisting of Nematoda (5 species), Rotatoria (2 species), Hirudinea (1 species), Aphanoneura (2 species), Gastropoda (1 species), Ostracoda (1 species), Copepoda (3 species), Amphipoda (3 species), Isopoda (1 species), Heteroptera (1 species) (cf. Sarbu 2000; Brad et al. 2015). Dendrocoelum obstinatum Stocchino \& Sluys, sp. nov. is one of the three top predators in the aquatic community of the sulfidic groundwaters at Mangalia, together with the leech Haemopis caeca Manoleli, Klemm \& Sarbu, 1998 and the heteropteran Nepa anophtalma Decu, Gruia, Keffer \& Sarbu, 1994 (cf. Sarbu \& Popa 1992 ).

\section{Sulfidic wells}

Planarians were collected from four old, hand-dug wells in the town of Mangalia. These wells are 0.8 to $2.5 \mathrm{~km}$ far from the cave (Table 1). Depth of the wells varies from 14 to $19 \mathrm{~m}$. Water temperature range is $18-19^{\circ} \mathrm{C}$. The temperature of the wells depends on the distance to the place where the fault system brings up the warm water (see above) to the surface and how long it takes the waters to flow through the
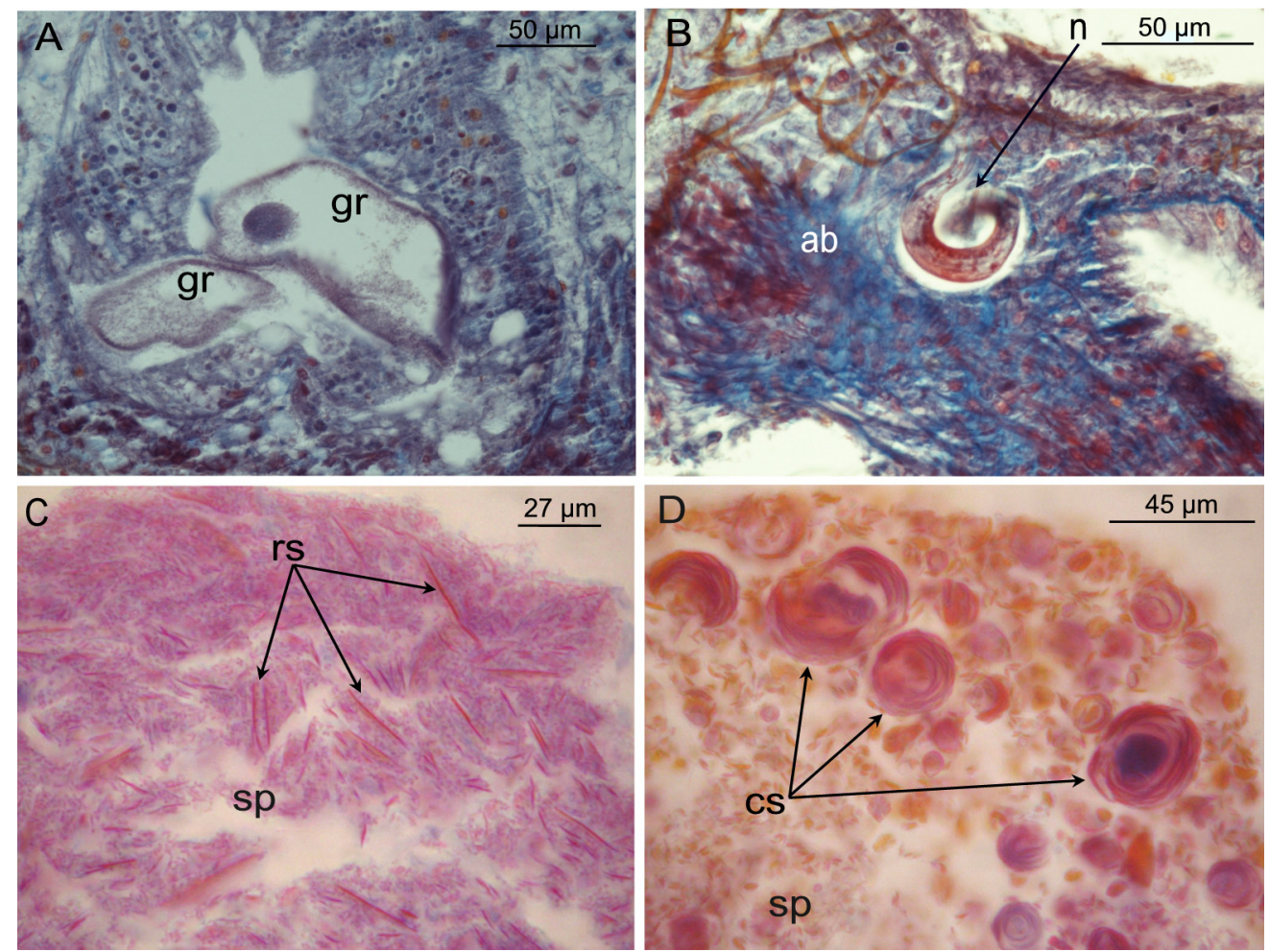

Fig. 5. Dendrocoelum obstinatum Stocchino \& Sluys, sp. nov. A. Holotype (ZMA V.P1. 7264.1), microphotograph of gregarine protozoans in a gut diverticulum. B. Specimen from the Movile Cave, microphotograph of a nematode infecting the bulb of the adenodactyl (ZMA V.P1. 7265.2). C. Holotype, microphotograph of the mass of sperm inside the copulatory bursa with the rod-like structures. D. Specimen from the Limanu well, microphotograph of the mass of sperm inside the copulatory bursa, with a multilayered concentric organization of the circular structures (ZMA V.P1. 7269.1). 
Table 1. List of sampling localities of Dendrocoelum obstinatum Stocchino \& Sluys, sp. nov., with their geographic coordinates and physico-chemical data. Not available data are indicated by -.

\begin{tabular}{|c|c|c|c|c|c|}
\hline Location & Coordinates & pH & $\mathbf{T}^{\circ} \mathbf{C}$ & $\mathrm{H}_{2} \mathrm{~S} \mathbf{m g} / \mathrm{l}$ & $\begin{array}{l}\text { Distance from } \\
\text { Movile Cave }\end{array}$ \\
\hline Movile Cave & $\begin{array}{l}43^{\circ} 49^{\prime} 36.28^{\prime \prime} \mathrm{N} \\
28^{\circ} 33^{\prime} 43.67^{\prime \prime} \mathrm{E}\end{array}$ & 7.04 & 21.02 & 8.03 & $0 \mathrm{~km}$ \\
\hline $\begin{array}{l}\text { General Dragalina street \# } 10 \text { well, } \\
\text { Mangalia }\end{array}$ & $\begin{array}{l}43^{\circ} 49^{\prime} 12.66^{\prime \prime} \mathrm{N} \\
28^{\circ} 34^{\prime} 07.68^{\prime \prime} \mathrm{E}\end{array}$ & - & - & sulfidic & ca $0.8 \mathrm{~km}$ East \\
\hline Neţoi street \# 1well, Mangalia & $\begin{array}{l}43^{\circ} 49^{\prime} 11.27^{\prime \prime} \mathrm{N} \\
28^{\circ} 34^{\prime} 12.79^{\prime \prime} \mathrm{E}\end{array}$ & 7.04 & 18.06 & 4.05 & ca $1 \mathrm{~km}$ East \\
\hline $\begin{array}{l}\text { Horia, Cloşca \& Crişan street \#13 well, } \\
\text { Mangalia }\end{array}$ & $\begin{array}{l}43^{\circ} 49^{\prime} 18.65^{\prime \prime} \mathrm{N} \\
28^{\circ} 33^{\prime} 23.05^{\prime \prime} \mathrm{E}\end{array}$ & 7.7 & 18.07 & sulfidic & ca $1.1 \mathrm{~km}$ East \\
\hline Aleea Cetăţii street \#1 well, Mangalia & $\begin{array}{l}43^{\circ} 48^{\prime} 52.95^{\prime \prime} \mathrm{N} \\
28^{\circ} 35^{\prime} 03.37^{\prime \prime} \mathrm{E}\end{array}$ & 7.42 & 19.03 & sulfidic & ca $2.5 \mathrm{~km}$ East \\
\hline 2 (Doi) Mai well & $\begin{array}{l}43^{\circ} 47^{\prime} 19.77^{\prime \prime} \mathrm{N} \\
28^{\circ} 34^{\prime} 34.82^{\prime \prime} \mathrm{E}\end{array}$ & - & ca 13 & $\begin{array}{l}\text { non- } \\
\text { sulfidic }\end{array}$ & ca $4.5 \mathrm{~km}$ South \\
\hline Limanu well & $\begin{array}{l}43^{\circ} 48^{\prime} 00.22^{\prime \prime} \mathrm{N} \\
28^{\circ} 31^{\prime} 34.82^{\prime \prime} \mathrm{E}\end{array}$ & - & ca 13 & $\begin{array}{l}\text { non- } \\
\text { sulfidic }\end{array}$ & ca $3.5 \mathrm{~km}$ South \\
\hline Vama Veche well & $\begin{array}{l}43^{\circ} 45^{\prime} 07.10^{\prime \prime} \mathrm{N} \\
28^{\circ} 34^{\prime} 20.48^{\prime \prime} \mathrm{E}\end{array}$ & - & ca 13 & $\begin{array}{l}\text { non- } \\
\text { sulfidic }\end{array}$ & ca $8.4 \mathrm{~km}$ South \\
\hline Albeşti well & $\begin{array}{l}43^{\circ} 48^{\prime} 45.63^{\prime \prime} \mathrm{N} \\
28^{\circ} 25^{\prime} 37.05^{\prime \prime} \mathrm{E}\end{array}$ & - & ca 13 & $\begin{array}{l}\text { non- } \\
\text { sulfidic }\end{array}$ & ca $11 \mathrm{~km}$ West \\
\hline
\end{tabular}

surface limestones. The $\mathrm{pH}$ value is around 7.0 with non-significant variations. Both in the cave and the sulfidic wells, $\mathrm{pH}$ values near neutrality depend on the great buffering capacity of the carbonate bedrock. Although $\mathrm{H}_{2} \mathrm{~S}$ oxidizes and forms sulphuric acid, this is immediately neutralized by the bicarbonate in the water (Sarbu 2000).

Planarian specimens were found only at the water surface. In the past all of these wells were used for drinking water. Planarians were not found in many other wells in the town that were also sampled. In the General Dragalina, Horia, Cloşca \& Crişan and Aleea Cetăţii wells planarians were found associated with Niphargus dancaui Brad, Fiser, Flot \& Sarbu, 2015 (Brad et al. 2015).

\section{Non-sulfidic wells}

Planarians were collected from four old, hand-dug wells in the villages of Limanu, 2 (Doi) Mai, Albeşti and Vama Veche, localized at a distance ca 3.5 to ca $11 \mathrm{~km}$ from Movile Cave. Specimens were seen moving on the limestone walls and descending to a depth of more than $1 \mathrm{~m}$. Water temperature of the non-sulfidic wells is ca $13^{\circ} \mathrm{C}$, which is the mean annual temperature of southern Dobrogea (Table 1).

\section{Discussion}

Dendrocoelum obstinatum Stocchino \& Sluys, sp. nov. shows a peculiar cervix-like protrusion at the caudal part of the male atrium, thus giving rise to an extreme reduction of the common atrium. Similar structures concern (a) the "atrial papilla" reported for two species from Romania viz. D. polymorphum Codreanu \& Balcesco, 1967 and D. stenophallus Codreanu \& Balcesco, 1967, (b) the "plug" described by Kenk (1978) for D. sinisai Kenk, 1978 from Lake Ohrid, (c) the papillate projection of the atrium in D. caspicum Porfirjeva \& Dyganova, 1973 and (d) in D. grimmi Dyganova, 1983. 
Dendrocoelum obstinatum differs from $D$. polymorphum in that in the latter species the male atrium is very long, due to the very anterior position of the papilla, and is surrounded by many layers of muscle fibres. Furthermore, in D. polymorphum the adenodactyl is positioned posterior to the penis papilla. This situation contrasts with that of $D$. obstinatum in which the penis is dorsal to the adenodactyl, while the male atrium is only of moderate dimensions and is surrounded by only two layers of muscles. Moreover, $D$. polymorphum is characterized by a strong musculature on the vaginal area of the bursal canal and by the large, elongated lumen of the adenodactyl, whereas in D. obstinatum the terminal tract of the bursal canal is surrounded by only two layers of musculature, while its adenodactyl shows a much smaller lumen, being less than half of the total length of the adenodactyl.

Gourbault (1972) reported the presence of D. polymorphum also from wells in 2 (Doi) Mai village. Our analysis of specimens from a well in this village suggests, however, that her animals may not belong to this species but to D. obstinatum. We admit that we do not know whether she obtained her specimens from the same well in which our animals were collected and that her description of the animals differs in some details from both D. obstinatum as well as from Codreanu \& Balcesco's (1967c) account of D. polymorphum. For example, Gourbault $(1967 b, 1972)$ reported for her animals (a) a penis bulb housing a distinct seminal vesicle, (b) a bursal canal that runs on the right side of the copulatory apparatus, and (c) an outer zone of pharyngeal muscles provided with only a single layer of circular muscles, being features that are absent or different in our specimens as well as those described by Codreanu \& Balcesco (1967c). Furthermore, according to Codreanu \& Balcesco (1967c), the subepithelial layer of circular muscle on the penis papilla terminates in a thickened ring, located well before the tip of the papilla; such a ring is not described by Gourbault (1967b, 1972).

Dendrocoelum stenophallus is characterized by an "inflexible flagellum" sensu Stocchino et al. (2013) (see also Sluys 2012), which is absent in D. obstinatum. The former species has also been described with an elongated muscular sphincter ("sphincter papilliforme") at the level of the atrial papilla. However, according to Sluys (2012) such a sphincter is not present in at least Gourbault's specimens of this species.

Dendrocoelum sinisai is easily distinguishable from $D$. obstinatum for its two eyes and by the different shape of its penis and the presence of a well defined seminal vesicle with pleated walls (Kenk 1978).

Dendrocoelum obstinatum differs from $D$. caspicum and D. grimmi, since these are species with multiple eyes and with a sphincter in the vaginal area of the bursal canal. Moreover D. caspicum is also provided with a pseudoflagellum (Porfirjeva \& Dyganova 1973, 1987; Dyganova 1983).

Another characteristic feature of D. obstinatum is the peculiar organization of the mass of sperm in the copulatory bursa. The presence of sclerotic rod-like structures (more or less circular in one population) of different sizes among this mass of sperm suggests that by means of the secretory material the spermatozoa are packed up into bundles containing a variable number of sperm cells. Given that sperm inside the vasa deferentia are free, it is very likely that the sperm became grouped only after transfer into the copulatory bursa, as a result of secretion produced by the lining epithelium of the bursa. Further, the presence of free sperm inside the oviducts indicates that the spermatozoa become free again when they pass into the ducts or just before their release from the copulatory bursa. Thus, the presence or absence of these sclerotic-like structures may be due to the physiological state of the animals. This kind of sperm aggregation, which has not been reported before for freshwater flatworms, could be interpreted as an adaptive strategy to protect the sperm from the extreme environmental condition. It resembles the "sperm conjugates" reported for a variety of species of insects, in which the sperm heads are embedded in a cup of extracellular material (cf. Higginson \& Pitnick 2011).

The precise nature of this sperm aggregation and disaggregation in D. obstinatum needs to be studied in more detail by means of future ultrastructural and/or histochemical analyses. 
Dendrocoelum obstinatum is characterized by the absence of spermatophores. Although these structures are considered a common mode of sperm transfer among freshwater planarians (cf. Sluys 1989) their presence is not a universal character among these flatworms. For example, among dendrocoelids spermatophores are also absent in D. mariae Stocchino \& Sluys, 2013, D. nuraghum Stocchino \& Sluys, 2013 and D. vesiculosum Stocchino \& Sluys, 2013 (G.A. Stocchino pers. obs.). Among invertebrates spermatophores usually occur in species that need to protect sperm during their transfer from males to females (cf. Vreys et al. 1997). Thus, apparently they are not necessary in freshwater triclads that have a well-developed copulatory apparatus and exhibit reciprocal copulation. However, it has been suggested that a selective advantage of the spermatophore may lie in its ability to protect sperm from being digested in the copulatory bursa, thus potentially increasing the success of a single insemination (Vreys et al. 1997). In this sense sperm packaging in the form of small packages of spermatozoa, such as in D. obstinatum, could be an alternative way to preserve them in the bursa and, thus, may be functionally similar to spermatophores. This adaptive strategy may be particularly useful in subterranean animals in which paucity of individuals in this habitat may restrict frequent meeting of partners.

The distinct narrowing of the proximal tract of the bursal canal lumen of $D$. obstinatum is a character shared with a number of species of the genus Dendrocoelum such as $D$. polymorphum, D. romanodanubialis (Codreanu, 1949), D. nuraghum, D. spatiosum Vila-Farrè \& Sluys, 2011 and D. vesiculosum. However, in all of these other species the lumen of the canal, although very narrow, is always patent, in contrast to the situation in D. obstinatum in which the lumen is reduced to such an extent that it is virtually absent.

In all specimens examined of $D$. obstinatum, the adenodactyl is characterized by the presence of a zone of fine circular muscle fibres that runs through the mesenchyme of the papilla. This particular adenodactyl anatomy, called the Balkan type, is shared by ten other species, viz. D. lacteum Müller, 1774 a widely distributed species in Europe, D. adenodactylosum (Stanković \& Komárek, 1927) and D. maculatum (Stanković \& Komárek, 1927) from Albania, D. constrictum Harrath \& Sluys, 2012, D. duplum Harrath \& Sluys, 2012 and D. amplum Harrath \& Sluys, 2012 from Tunisia (Harrath et al. 2012), D. nekoum Sluys, 2012 from Switzerland (Sluys 2012) and D. mariae, D. nuraghum and D. vesiculosum from Sardinia (Stocchino et al. 2013). The discovery of the Balkan type of adenodactyl in Romanian animals as well enlarges the geographic range of this character and corroborates the wide distribution of this character among Dendrocoelum species, as already hypothesised by Harrath et al. (2012).

Among flatworms gregarine sporozoans infest a wide variety of hosts such as freshwater and terrestrial Tricladida, Polycladida and Prolecitophora (Desportes 2013). However, until now only a report exists on the infestation of one subterranean species of triclad by gregarines, viz. Dendrocoelum tismanae Codreanu \& Balcesco, 1967 (Codreanu \& Balcesco 1971). Interestingly, this species, infested by Monocystella spelaea Codreanu \& Balcesco, 1971, is endemic to a Romanian cave.

Besides protozoan parasites, one specimen of $D$. obstinatum was found to be infested by a nematode. The fact that this parasite infested the adenodactyl bulb contrasts with previous records in which nematodes were found to be infesting the pharynx tissues of several species of freshwater planarian (cf. Kawakatsu 1970; Ball \& Reynoldson 1981). To the best of our knowledge this is the first record of a nematode parasitizing a subterranean planarian species. We do not know if the life cycle of this particular species of nematode has a free-living larval stage, as is the case in many nematodes. Interestingly, the metazoan fauna of the mats in the Movile Cave is dominated by dense populations of five bacterivorous nematode species, which, however, are reported with a free-living life style (cf. Riess et al. 1999; Muschiol et al. 2015). Thus, this represents the first record of a parasitic nematode for this ecosystem. According to Ball \& Reynoldson (1981: 32): "It is not known what the relationship between the nematodes and the planarian might be." 
With respect to the Movile Cave biotope, the presence of worms at the surface film of the water, rather than on the limestone walls - as they do in the non-sulfidic wells - appears to be consistent with the behaviour of other species in this environment since all other aquatic fauna is here also restricted to the top water layer (1-10 cm) (Sarbu \& Popa 1992).

The presence of $D$. obstinatum in the peculiar Movile Cave raises two questions: (1) do the animals show any anatomical adaptations to the unusual cave conditions, and (2) when did the worms enter the cave system? The anatomy of D. obstinatum is in accordance with that of other species of Dendrocoelum from either caves or epigean habitats and, thus, does not suggest any specific adaptations to the chemoautotrophic ecosystem, except, perhaps, the aggregation of sperm after transfer from one partner to the other (see above). The species is not endemic to the cave and also occurs in some nearby sulfidic and in non-sulfidic wells, up to about $11 \mathrm{~km}$ from the cave, and, therefore, it can be concluded that D. obstinatum is not dependent on the sulfidic conditions. It represents the first species of triclad able to live both in sulfidic and non-sulfidic waters.

Moreover, among the fauna of the Mangalia sulfidic ecosystem D. obstinatum is the only species also found outside the current boundaries of the sulfidic aquifer. In contrast, most of the groundwater fauna in this region is either limited to the sulfidic waters or occurs only in non-sulfidic wells and springs (Sarbu 2000).

According to its currently known distribution, $D$. obstinatum is limited to the old boundaries of the sulfidic aquifer that was present in the region and that later became much smaller and currently supplies the water for the groundwater system in the Mangalia region (cf. Sarbu 2000). There is also evidence that the old sulfidic aquifer became fragmented and that today there is a second sulfidic reservoir close to the village of Hagieni, located approximately $10 \mathrm{~km}$ west of Mangalia (Sarbu 2000). Thus, it may be the case that the planarian species has survived in areas that today are no longer sulfidic but were sulfidic at an earlier stage in the history of $D$. obstinatum and, hence, this species may be considered an indicator of the extension of the sulfidic aquifer in the past of the Mangalia region.

An alternative scenario would be that the species more recently colonized the cave ecosystem from the surrounding non-sulfidic area, but when this took place and on how many occasions currently remains wrapped up in a shroud of mystery.

\section{Biogeography of Romanian dendrocoelids}

The majority of Romanian dendrocoelids have been reported from the western part of this country corresponding to the Transylvania, Oltenia and Banat regions (Fig. 1, Table 2). Out of a total of 19 nominal species of Dendrocoelum reported from Romania, 17 are endemic to this country ( $90 \%$ of endemicity) (Fig. 1, Table 2). The only non-endemic species are D. lipophallus (De Beauchamp, 1929), reported also from the Caucasus, and $D$. lacteum, with a very large distributional range across the Palaearctic Region. All Romanian species, except $D$. romanodanubialis and D. lacteum are recorded from subterranean habitats, such as caves, springs, wells and hyporheic systems (Fig. 1, Table 2). Considering all species of Dendrocoelum, about 1/5 th (19 out of 90 species, see above) has been reported from Romania.

Among subterranean Dendrocoelidae, three species of the genus Polycladodes have been reported also from Romania, viz. P. affine Codreanu \& Balcesco, 1970 and P. voinovi (Codreanu, 1929), endemic to this country, and P. album (Steinmann, 1910) (cf. Gourbault 1972, 1986).

According to Codreanu \& Balcesco (1967a) the presence of such a high number of endemic subterranean species in Romania could be related to the palaeogeographic vicissitudes that occurred in this region at 
Table 2. Checklist of species of the genus Dendrocoelum Örsted, 1844 from Romania.

\begin{tabular}{|c|c|c|c|c|}
\hline Species & Locality & $\begin{array}{c}\text { Endemic } \\
\text { species }\end{array}$ & Habitat & References \\
\hline $\begin{array}{l}\text { D. obstinatum } \\
\text { Stocchino \& Sluys, sp. nov. }\end{array}$ & $\begin{array}{l}\text { Dobrogea: Movile Cave, Mangalia } \\
\text { wells, Doi Mai well, Albesti well, } \\
\text { Limanu well, Vama Veche well }\end{array}$ & + & cave, well & Present paper \\
\hline $\begin{array}{l}\text { D. alexandrinae } \\
\text { Codreanu \& Balcesco, } 1970\end{array}$ & $\begin{array}{l}\text { Transylvania: Vama Buzaului, } \\
\text { Urlatoarea hydrographic basin }\end{array}$ & + & resurgence & $\begin{array}{l}\text { Codreanu \& Balcesco } \\
\text { 1970; Gourbault } 1972\end{array}$ \\
\hline $\begin{array}{l}\text { D. atriostrictum } \\
\text { Codreanu \& Balcesco, } 1967\end{array}$ & $\begin{array}{c}\text { Banat: Resita, Carasova, Sereniak } \\
\text { hydrographic basin }\end{array}$ & + & spring & $\begin{array}{l}\text { Codreanu \& Balcesco } \\
\text { 1967a,b; Gourbault } \\
1972\end{array}$ \\
\hline $\begin{array}{l}\text { D. banaticum } \\
\text { Codreanu \& Balcesco, } 1967\end{array}$ & $\begin{array}{l}\text { Banat: Oravita, Braduletul de Jos, } \\
\text { Cuptor, Stirmine hydrographic basin }\end{array}$ & + & spring & $\begin{array}{l}\text { Codreanu \& Balcesco } \\
\text { 1967a,b; Gourbault } \\
\text { 1967a, } 1972\end{array}$ \\
\hline $\begin{array}{l}\text { D. botosaneanui } \\
\text { Del Papa, } 1965\end{array}$ & Banat: Anina, Ponor Plan Cave & + & cave & $\begin{array}{l}\text { Del Papa 1965; } \\
\text { Gourbault } 1972\end{array}$ \\
\hline $\begin{array}{l}\text { D. brachyphallus } \\
\text { (De Beauchamp, 1929) }\end{array}$ & $\begin{array}{l}\text { Bihar: Vascau, Baita, Varnita Cave, } \\
\text { Portile Biharului Cave; Turda: Baia } \\
\text { de Aries }\end{array}$ & + & cave, spring & $\begin{array}{l}\text { De Beauchamp 1929; } \\
\quad \text { Gourbault } 1972\end{array}$ \\
\hline $\begin{array}{l}\text { D. chappuisi } \\
\text { De Beauchamp, } 1932\end{array}$ & Dobrogea: Tulcea, Babadag wells & + & well & $\begin{array}{l}\text { De Beauchamp 1932; } \\
\quad \text { Gourbault } 1972\end{array}$ \\
\hline $\begin{array}{l}\text { D. clujanum } \\
\text { Codreanu, } 1943\end{array}$ & Transylvania: Cluj well & + & well & $\begin{array}{l}\text { Codreanu 1943; } \\
\text { Gourbault } 1972\end{array}$ \\
\hline $\begin{array}{l}\text { D. debeauchampianum } \\
\text { Codreanu \& Balcesco, } 1967\end{array}$ & $\begin{array}{c}\text { Banat: Orsova, Cornereva, Ogasul } \\
\text { Ulmului }\end{array}$ & + & spring & $\begin{array}{l}\text { Codreanu \& Balcesco } \\
\text { 1967a,b; Gourbault } \\
1972\end{array}$ \\
\hline $\begin{array}{l}\text { D. geticum } \\
\text { Codreanu \& Balcesco, } 1970\end{array}$ & $\begin{array}{l}\text { Bucarest surroindings: Ciolpani } \\
\text { wells, Vidra wells }\end{array}$ & + & well & $\begin{array}{l}\text { Codreanu \& Balcesco } \\
\text { 1970; Gourbault } 1972\end{array}$ \\
\hline $\begin{array}{l}\text { D. lacteum } \\
\text { (Müller, 1774) }\end{array}$ & unspecified localities & - & $\begin{array}{l}\text { surface water } \\
\text { courses }\end{array}$ & $\begin{array}{c}\text { cf. Dahm \& Gourbault } \\
1978\end{array}$ \\
\hline $\begin{array}{l}\text { D. lipophallus } \\
\text { (De Beauchamp, 1929) }\end{array}$ & $\begin{array}{l}\text { Turda: Iara, Izvoarele village, } \\
\text { Izvourul de la Valau spring; } \\
\text { Caucasus }\end{array}$ & - & $\begin{array}{l}\text { spring, surface } \\
\text { water course }\end{array}$ & $\begin{array}{l}\text { De Beauchamp 1929, } \\
\text { 1932; Porfirjeva 1958; } \\
\text { Gourbault } 1972\end{array}$ \\
\hline $\begin{array}{l}\text { D. orghidani } \\
\text { Codreanu \& Balcesco, } 1967\end{array}$ & $\begin{array}{c}\text { Banat: Lipova, Caprioara, lui Dutu } \\
\text { Cave }\end{array}$ & + & cave & $\begin{array}{c}\text { Codreanu \& Balcesco } \\
\text { 1967c; Gourbault } \\
1972\end{array}$ \\
\hline $\begin{array}{l}\text { D. polymorphum } \\
\text { Codreanu \& Balcesco, } 1967\end{array}$ & $\begin{array}{l}\text { Dobrogea: Gura Dobrogei wells, } \\
\text { Agigea wells, Doi Mai wells }\end{array}$ & + & well & $\begin{array}{l}\text { Codreanu \& Balcesco } \\
\text { 1967c; Gourbault } \\
1967 b, 1972\end{array}$ \\
\hline $\begin{array}{l}\text { D. racovitzai } \\
\text { De Beauchamp, } 1949\end{array}$ & $\begin{array}{l}\text { Oltenie: Mehedinti, Closani, } \\
\text { Lazului Cave }\end{array}$ & + & cave & $\begin{array}{l}\text { De Beauchamp 1949; } \\
\quad \text { Gourbault } 1972\end{array}$ \\
\hline $\begin{array}{l}\text { D. romanodanubialis } \\
\text { (Codreanu, 1949) }\end{array}$ & Banat: Cazane, Danubie River & + & $\begin{array}{l}\text { surface water } \\
\text { course }\end{array}$ & $\begin{array}{l}\text { Codreanu 1949, 1950; } \\
\quad \text { Gourbault } 1972\end{array}$ \\
\hline $\begin{array}{l}\text { D. sphaerophallus } \\
\text { (De Beauchamp, 1929) }\end{array}$ & Hunedoara: Pui, Parospestere Cave & + & cave & $\begin{array}{l}\text { De Beauchamp 1929, } \\
\text { 1932; Gourbault } 1972\end{array}$ \\
\hline $\begin{array}{l}\text { D. stenophallus } \\
\text { Codreanu \& Balcesco, } 1967\end{array}$ & $\begin{array}{l}\text { Oltenie: Calugareni, Tihomirului } \\
\text { Cave; Mountains Mehedinti, } \\
\text { Sohodoalele Mici Cave }\end{array}$ & + & cave & $\begin{array}{c}\text { Codreanu \& Balcesco } \\
\text { 1967b; Gourbault } \\
1972\end{array}$ \\
\hline $\begin{array}{l}\text { D. tismanae } \\
\text { Codreanu \& Balcesco, } 1967\end{array}$ & $\begin{array}{c}\text { Oltenie: Gorj, Minastirea Tismana } \\
\text { Cave }\end{array}$ & + & cave & $\begin{array}{c}\text { Codreanu \& Balcesco } \\
\text { 1967b; Gourbault } \\
1972\end{array}$ \\
\hline
\end{tabular}


the end of the Tertiary, during which the sedimentation of large lake basins progressively forced epigean species towards springs and to the groundwater, thus ensuring the survival of these relict species.

\section{Acknowledgements}

We are grateful to Drs I. Desportes (Muséum national d'Histoire naturelle, Paris, France), H. Harrath and L. Mansour (King Saud University, Riyadh, Saudi Arabia) for helping with the identification of the protozoan parasites. Prof. M. Pala is thanked for her kind support. This research was supported by a Temminck Fellowship of Naturalis Biodiversity Center, Leiden, The Netherlands and by SYNTHESYS, the European Union-funded Integrated Activities grant (project grant: NL-TAF 3687) to G.A. Stocchino. We acknowledge financial support from the Regione Autonoma Sardegna (RAS2012LR7/2007-CRP-60215 "Conservazione e valorizzazione delle grotte sarde: biodiversità e ruolo socioeconomico-culturale”), Fondazione Banco Sardegna, Italian Ministero dell'Istruzione, dell’Università e della Ricerca (MIUR-PRIN) and INTERREG-EU.

\section{References}

Ball I.R. \& Reynoldson T.B. 1981. British Planarians. Cambridge University Press, Cambridge.

Brad T., Fišer C., Flot J.F. \& Sarbu S.M. 2015. Niphargus dancaui sp. nov. (Amphipoda, Niphargidae) a new species thriving in sulfidic groundwaters in southeastern Romania. European Journal of Taxonomy 164: 1-28. https://doi.org/10.5852/ejt.2015.164

Bromley H.J. 1982. The morphology, karyology and reproduction of a new species of Dendrocoelum Örsted (Turbellaria, Tricladida) from the headwaters of the river Jordan. Israel Journal of Zoology 31: 119-136.

Codreanu R. 1929. Polycladodes voinovi, n. sp., nouveau Triclade obscuricole de Roumanie. Comptes rendus des séances de la Société de Biologie (Paris) 101: 963-965.

Codreanu R. 1943. Dendrocoelum (sous-genre Dendrocoelides) clujanum n. sp. nouveau triclade souterrain de Transylvanie. Analele Academiei Române, Memoriile Sencţiunii Stienţifice 18: 135-158.

Codreanu R. 1949. Sur un nouveau Triclade oculé du défilé du Danube: Palaedendrocoelum romanodanubialis n. g., n. sp. Bulletin biologique de la France et de la Belgique 83: 284-287.

Codreanu R. 1950. O noua triclada relicta din defileul Dunarii: Palaedendrocoelum danubialis n. g., n. sp. (Un nouveau Triclade épigé relique du défilé du Danube: Palaedendrocoelum danubialis n. g., n. sp.). Analele Academiei Republicii Populare Române, Seria Geologie, Geografie, Biologie, Stiinte tehnice şi agricole 3: 599-642.

Codreanu R. \& Balcesco D. 1967a. Sur trois Dendrocoelides aveugles nouveaux des sources du Banat (Roumanie). Revue Roumaine de Biologie, Série de Zoologie 12: 287-294.

Codreanu R. \& Balcesco D. 1967b. Sur les rapports entre les sous-genres Paradendrocoelum Kenk 1930 et Dendrocoelides De Beauchamp 1919 d'après les espèces obscuricoles du Banat et de l'Olténie. Revue Roumaine de Biologie, Série de Zoologie 12: 337-349.

Codreanu R. \& Balcesco D. 1967c. Sur deux nouveaux Dendrocoeles hypogés de Roumanie et certains effets de néoténie. Archives Roumaines de Pathologie Expérimentale et de Microbiologie 46: 843-852.

Codreanu R. \& Balcesco D. 1970. Répartition des Dendrocoelides anophtalmes dans les Carpates de Corbure et dans la Plaine Roumanie. In: Orghidan T., Dimitresco M., Pop E., Murgeanu G., Codreanu R., Motas C., Puscariu V., Coman D., Tanasachi J., Serban M. \& Tabacaru I. (eds) Livre di Centenaire Emile Racovitza, 1868-1968: 239-246. Académie de la République Socialiste de Roumanie, Bucarest. 
Codreanu R. \& Balcesco D. 1971. Sur une nouvelle grégarine, Monocystella spelaea n. sp. parasite d'un dendrocoelide cavernicole de Roumanie et la systématique des acéphalines des turbellariés. Protistologica 7: 145-152.

Dahm G.A. \& Gourbault N. 1978. Tricladida et Temnocephalida (Turbellaria). In: Illies J. (ed.) Limnofauna Europaea: 16-20. Fischer, Stuttgart.

De Beauchamp P. 1928. Nouvelles diagnoses de Triclades obscuricoles, I. Planaria racovitzai n. sp. Bulletin de la Société Zoologique de France 53: 510-513.

De Beauchamp P. 1929. Nouvelles diagnoses de Triclades obscuricoles, II. Les Dendrocoelides de Transylvanie. Bulletin de la Société Zoologique de France 54: 20-28.

De Beauchamp P. 1932. Turbellariés, Hirudinées, Branchiobdellidés: Biospeleologica 58, ser. 2. Archives de Zoologie Expérimentale et Générale 73: 113-380.

De Beauchamp P. 1949. Turbellariés, Hirudinées, Branchiobdellidés: Biospeleologica 69, ser. 3. Archives de Zoologie Expérimentale et Générale 86: 50-65.

Del Papa R. 1965. Descrizione di Dendrocoelum (Eudendrocoelum) botosaneanii n. sp. delle grotte del Banato (Romania). Monitore Zoologico Italiano 73: 156-162.

Desportes I. 2013. Systematics of terrestrial and fresh water gregarines. In: Desportes I. \& Schrevel J. (eds) Treatise on Zoology, Anatomy, Taxonomy, Biology. The gregarines: 2: 377-710. Brill, Leiden, The Netherlands. https://doi.org/10.1163/9789004256057006

Dyganova R.Ya. 1983. Resnichnye chervi (Turbellaria, Tricladida) Kaspiyskogo morya [Turbellarians of the Caspian Sea]. Publication Office of the University of Kazan, Kazan. [in Russian]

Dyganova R.Ya. 1988. Species structures and zoogeographical relations of triclads of the European part of the URSS. In: Ax P., Ehlers U. \& Sopott-Ehlers B. (eds) Free-living and Symbyotic Plathelminthes, Fortschritte der Zoologie/Progress in Zoology: 36: 517-521. Gustav Fischer Verlag, Stuttgart, New York.

Gourbault N. 1967a. Triclades obscuricoles de Roumanie. I Dendrocoelides du Banat. Bulletin du Muséum national d'Histoire naturelle 39: 745-752.

Gourbault N. 1967b. Triclades obscuricoles de Roumanie. II Dendrocoelides de Dobroudja et d'Olténie. Annales de Spéléologie 22: 803-813.

Gourbault N. 1972. Recherches sur les Triclades Paludicoles hypogés. Mémoires du Muséum national d'Histoire naturelle, série A Zoologie 73, Muséum national d'Histoire naturelle, Paris.

Gourbault N. 1986. Turbellaria Tricladida. In: Botosaneanu L. (ed.) Stygofauna Mundi. A Faunistic, Distributional, and Ecological Synthesis of the World Fauna Inhabiting Subterranean Waters (Including the Marine Interstitial): 57-71. E.J. Brill/W. Backhuys, Leiden.

Harrath H.A., Sluys R., Ghlala A. \& Alwasel S. 2012. The first subterranean freshwater planarians from North Africa, with an analysis of adenodactyl structure in the genus Dendrocoelum (Platyhelminthes, Tricladida, Dendrocoelidae). Journal of Cave and Karst Studies 74: 48-57. https:// doi.org/10.4311/2011LSC0215

Higginson D.M. \& Pitnick S. 2011. Evolution of intra-ejaculate sperm interactions: do sperm cooperate? Biological Reviews 86: 249-270. https://doi.org/10.1111/j.1469-185X.2010.00147.x

Kenk R. 1978. The planarians (Turbellaria: Tricladida Paludicola) of the Lake Ohrid in Macedonia. Smithsonian Contributions to Zoology 280: 1-56. https://doi.org/10.5479/si.00810282.280 
Kawakatsu M. 1970. Parasites of Turbellarians: records of several species of endoparasites of freshwater planarians. The Research Bulletin of the Meguro Parasitological Museum 3: 37-47.

Muschiol D., Giere O. \& Traunsporger W. 2015. Population dynamics of a cavernicolous nematode community in a chemoautotrophic groundwater system. Limnology and Oceanography 60: 127-135. https://doi.org/10.1002/lno.10017

Negrea S. 2007. Historical development of biospeleology in Romania after the death of Emile Racovitza. Travaux de l'Institut de Spéologie «Emile Racovitza» 45/46: 131-167.

Porfirjeva N.A. 1958. Planarii Kavkaza [Planarians of the Caucasus]. Trudy Obshchestva Estestvoispytateleu pri Kazanskom gosudarstvennom Universitete 62: 39-89. [in Russian]

Porfirjeva N.A. \& Dyganova R.Ya. 1973. Dendrocoelum caspicum sp. n. (Tricladida, Paludicola) iz Kaspiia i ego zoogeograficheskie otnosheniia [Dendrocoelum caspicum sp. n. from the Caspian Sea and its zoogeographical Relations]. Zoologicheskii Zhurnal 52: 982-987. [in Russian]

Porfirjeva N.A. \& Dyganova R.Ya. 1987. Planarii europeiskoi ciasti SSSR [Planarians of the European part of the USSR - Morphology, Systematics, Distribution]. University of Kazan. [in Russian]

Riess W., Giere O., Kohls O. \& Sarbu S.M. 1999. Anoxic thermomineral cave waters and bacterial mats as habitat for freshwater nematodes. Aquatic Microbial Ecology 18: 157-164. https://doi.org/10.3354/ $\underline{\text { ame } 018157}$

Sarbu S.M. 2000. Movile Cave: a chemoautotrophically based groundwater ecosystem. In: Wilkins H., Culver D.C. \& Humphreys W.F. (eds) Ecosystems of the World 30. Subterranean Ecosystems: 319-343. Elsevier Academic Press, Amsterdam.

Sarbu S.M. \& Popa R. 1992. A unique chemoautotrophically based cave ecosystem. In: Camacho A.I. (ed.) The Natural History of Biospeleology: 637-666. Monograph of the National Museum of Natural Sciences 7, Madrid, Spain.

Sarbu S.M., Kane T.C. \& Kinkle B.K. 1996. A chemoautotrophically based groundwater ecosystem. Science 272: 1953-1955. https://doi.org/10.1126/science.272.5270.1953

Sluys R. 1989. Phylogenetic relationships of the triclads (Platyhelminthes, Seriata, Tricladida). Bijdragen tot Dierkunde 59: 3-25.

Sluys R. 2012. A new, sibling species of cave flatworm from Switzerland (Platyhelminthes, Tricladida, Dendrocoelidae). Revue Suisse de Zoologie 119: 181-188. https://doi.org/10.5962/bhl.part.150024

Sluys R. \& Benazzi M. 1992. A new finding of a subterranean dendrocoelid flatworm from Italy (Platyhelminthes, Tricladida, Paludicola). Stygologia 7: 213-217.

Stocchino G.A., Sluys R., Marcia P. \& Manconi R. 2013. Subterranean aquatic planarians of Sardinia, with a discussion on the penial flagellum and the bursal canal sphincter in the genus Dendrocoelum (Platyhelminthes, Tricladida, Dendrocoelidae). Journal of Cave and Karst Studies 75: 93-112. https:// doi.org/10.4311/2011LSC0252

Vila-Farrè M., Sluys R., Almagro Í., Handberg-Thorsager M. \& Romero R. 2011. Freshwater planarians (Platyhelminthes, Tricladida) from the Iberian Peninsula and Greece: diversity and notes on ecology. Zootaxa 2779: 1-38.

Vreys C., Schockaert E.R. \& Michiels N.K. 1997. Formation, transfer and assimilation of the spermatophore of the hermaphroditic flatworm Dugesia gonocephala (Tricladida, Paludicola). Canadian Journal of Zoology 75: 1479-1486. https://doi.org/10.1139/z97-771 
Manuscript received: 9 December 2016

Manuscript accepted: 15 March 2017

Published on: 8 August 2017

Topic editor: Rudy Jocqué

Desk editor: Kristiaan Hoedemakers

Printed versions of all papers are also deposited in the libraries of the institutes that are members of the EJT consortium: Muséum national d'Histoire naturelle, Paris, France; Botanic Garden Meise, Belgium; Royal Museum for Central Africa, Tervuren, Belgium; Natural History Museum, London, United Kingdom; Royal Belgian Institute of Natural Sciences, Brussels, Belgium; Natural History Museum of Denmark, Copenhagen, Denmark; Naturalis Biodiversity Center, Leiden, the Netherlands; Museo Nacional de Ciencias Naturales-CSIC, Madrid, Spain; Real Jardín Botánico de Madrid CSIC, Spain. 